\title{
Prima Krim sebagai Solusi Penyembuh Luka pada Penderita Diabetes Melitus
}

\section{The Prima Cream as Solutions for Wound Healer on Diabetes Mellitus Patients}

\author{
Rahmad Dwi Ardhiansyah ${ }^{1 *}$, Riefky Pradipta Baihaqie ${ }^{1}$, Muhammad Nuriy Nuha Naufal ${ }^{1}$, \\ Muhamad Atabika Farma Nanda ${ }^{1}$, Kurnia Rahmawati ${ }^{2}$, Yuda Heru Fibrianto ${ }^{1}$ \\ ${ }^{1}$ Fakultas Kedokteran Hewan, Universitas Gadjah Mada, \\ ${ }^{2}$ Fakultas Farmasi, Universitas Gadjah Mada \\ "Email: rahmad.dwi.a@mail.ugm.ac.id
}

Naskah diterima : 24 Januari 2018, direvisi : 30 November 2018, disetujui : 18 Januari 2019

\begin{abstract}
Number of patients with diabetes mellitus are very large, according to International Diabetes Federation (IDF) in 2013 reaches 382 billion people between the ages of 40-59 years. Diabetic has been characterized as a chronic wounds. The animal blood waste from a slaugther house is still untapped, containing PRP (Platelet Rich Plasma) that can accelerates heal of bone and soft tissue. PRP (Platelet Rich Plasma) was made from the cattle blood waste using centrifugation. The purpose of the study is to prove that the Prima cream can heal the wounds in diabetic patients. Animals used in this study is 20 Wistar rats. Induction of diabetes was using streptozootocin $65 \mathrm{mg} / \mathrm{kg}$ and nicotinamide $235 \mathrm{mg} / \mathrm{kg}$. The animal were divided into 4 groups: non-diabetes given placebo (ND-), diabetes given placebo (DM-), diabetic rat given commercial drug were containing chloramphenicol base $20 \mathrm{mg}+$ prednisolone 2.5 $\mathrm{mg}(\mathrm{DM}+)$, and diabetes given cream PRP at $20 \%$ concentration (DM PRP). Parameters used to measure the rate of wound healing is wound size and histopathologic examination. The data were analyzed using Anova One Way at 95\% significant rate. PRP DM group had a wound healing faster than ND- group, DM- and DM+. Based on histopathologic examination, such as epitelialization, basal membrane, fibroblasts, collagen tissue, and presence of inflammatory cells, the best curing reaction was showed in DM PRP. PRP $20 \%$ cream produces from cow blood waste can accelerate wound healing in diabetes mellitus.
\end{abstract}

Keywords: Cow blood waste; Diabetes mellitus wound; Platelet Rich Plasma

\begin{abstract}
Abstrak
Jumlah penderita diabetes melitus sangat besar, menurut International Diabetes Federation (IDF) pada tahun 2013 mencapai 382 milyar orang dengan usia antara 40-59 tahun. Luka diabetik dikarakteristikkan sebagai luka kronis yang memiliki waktu penyembuhan yang lama. Limbah darah di Rumah Potong Hewan selama ini masih belum termanfaatkan, sementara darah tersebut memiliki PRP (Platelet Rich Plasma) yang mampu mempercepat penyembuhan tulang dan jaringan lunak. Pembuatan PRP (Platelet Rich Plasma) dari darah sapi dilakukan dengan metode sentrifus. Tujuan penelitian adalah membuktikan bahwa Prima Krim mampu menyembuhkan luka pada penderita Diabetes Melitus. Hewan coba yang digunakan dalam penelitian ini adalah 20 ekor tikus galur wistar. Induksi diabetes menggunakan streptozootocin $65 \mathrm{mg} / \mathrm{kg}$ dan nicotinamide $235 \mathrm{mg} / \mathrm{kg}$. Hewan percobaan dibagi menjadi 4 kelompok yaitu non diabetes diberi placebo (ND-), diabetes diberi placebo (DM-), diabetes diberi obat komersil yang mengandung kloramfenikol basa $20 \mathrm{mg}+$ prednisolon 2,5 $\mathrm{mg}(\mathrm{DM}+$ ) dan diabetes diberi krim PRP dengan konsentrasi 20\% (DM PRP). Parameter yang dipakai untuk mengetahui tingkat kesembuhan luka adalah diameter luka dan pemeriksaan histopatologi. Data dianalisis menggunakan Anova One Way pada derajat signifikansi 95\%. Hasil penelitian menunjukkan DM PRP memiliki tingkat kesembuhan luka yang lebih baik daripada kelompok ND-, DM- dan DM+. Berdasarkan pembacaan preparat histopatologi (melalui skoring epitelialisasi, membrana basalis, fibroblast, jaringan kolagen, dan ada tidaknya sel radang), didapatkan hasil kesembuhan terbaik ditunjukkan pada DM PRP. Krim PRP 20\% yang dihasilkan dari limbah darah sapi mampu memberikan kesembuhan luka pada penderita diabetes melitus.
\end{abstract}

Kata kunci: Limbah darah sapi; luka diabetes melitus; Platelet Rich Plasma 


\section{Pendahuluan}

Jumlah penderita diabetes melitus sangat besar, menurut International Diabetes Federation (IDF) pada tahun 2013 mencapai 382 milyar orang dengan usia antara 40 sampai 59 tahun, dan pada tahun 2035 semua jenis diabetes akan meningkat khususnya tipe 2 sebesar 55\% atau sebanyak 592 milyar orang. Indonesia menempati peringkat 7 dari negara yang memiliki jumlah penderita diabetes terbanyak, yaitu sebanyak 8,5 milyar orang (Anonim, 2013). Menurut Margolis dkk (1999) luka diabetik dikarakteristikkan sebagai luka kronis yang memiliki waktu penyembuhan yang lama. Apabila menggunakan perawatan luka standar, lama waktu penyembuhan luka dapat mencapai 12-20 minggu. Luka diabetik yang tidak sembuh dapat menyebabkan infeksi dan ini merupakan penyebab utama dilakukannya tindakan amputasi.

Rumah Potong Hewan (RPH) adalah suatu bangunan atau kompleks bangunan dengan desain dan syarat tertentu yang digunakan sebagai tempat memotong hewan bagi konsumsi masyarakat umum (Anonim, 2010). Salah satu hewan yang disembelih di RPH adalah sapi. Seekor sapi dapat menghasilkan limbah darah kurang lebih sebanyak 28 liter. Jika limbah darah ini dibuang ke badan air, maka dapat mencemari air dan akan berdampak pada kualitas fisik air yaitu warna, $\mathrm{pH}$, total padatan terlarut. Padatan tersuspensi, kandungan lemak, Biological Oxygen Demand (BOD), ammonium, nitrogen, dan fosfor juga akan mengalami peningkatan. Hal tersebut dapat menurunkan kualitas air dan mengganggu kesehatan apabila dikonsumsi (Sanjaya dkk,1996)

Komponen darah terdiri dari plasma, sel darah merah, sel darah putih dan platelet. Platelet atau trombosit merupakan sel darah yang berbentuk diskoid kecil (1-3 $\mu \mathrm{m})$ (Evert, 2006). Platelet Rich Plasma (PRP) merupakan platelet yang terkonsentrasi pada sedikit plasma. PRP mengandung growth factor yang dapat mempercepat penyembuhan tulang dan jaringan lunak. PRP merupakan teknik baru penyembuhan jaringan dan seluler. PRP adalah volume plasma yang mengandung konsentrasi platelet diatas kadar normal. Kadar platelet normal pada darah memiliki rentang antara $150.000 / \mu 1$ dan $300.000 / \mu 1$ dengan nilai ratarata $200.000 / \mu 1$. PRP mengandung 1.000 .000 platelet/ $\mu 1$ dimana telah terbukti mampu meningkatkan penyembuhan pada tulang dan jaringan lunak (Marx, 2001).

Platelet Rich Plasma (PRP) yang telah dicampurkan dengan basis krim dapat digunakan sebagai obat oles pada luka. Basis krim berfungsi untuk mediator sehingga dapat melekat pada luka dan aman digunakan. Berdasarkan penelitian sebelumnya didapatkan hasil bahwa krim PRP mampu menyembuhkan luka bakar, krim PRP dengan konsentrasi 20\% memiliki kemampuan penyembuhan luka paling efisien (Ardhiansyah dkk, 2014).

Tujuan dari penelitian ini adalah untuk membuktikan Prima krim yang mengandung PRP dari limbah darah sapi mampu menyembuhkan luka pada penderita diabetes melitus.

\section{Materi dan metode}

Penelitian akan dilaksanakan di Laboratorium Patologi Klinik Fakultas Kedokteran Hewan, Laboratorium Teknologi Obat Fakultas Farmasi, Laboratorium Ilmu Hewan Laboratorium, Laboratorium Hewan Coba Pusat Studi Antar Universitas UGM dan Rumah Potong Hewan Giwangan Yogyakarta.

Peralatan yang digunakan dalam penelitian ini adalah gloves, tabung reaksi, mikropipet, sentrifugator, kandang tikus, container box, mikroskop, pH meter, mikrohematokrit, skalpel, objek glass, spuit, mikropipet, glucose test kit, 
Rahmad Dwi Ardiansyah, et. al.

spectrofotometer, milimeter blok. Bahan yang digunakan adalah tikus, darah sapi, streptozotocin, aquadest, pakan tikus, alkohol, EDTA, ketamine, xylazin, atropin sulfat, nicotinamide.

\section{Pembuatan Krim Platelet Rich Plasma (PRP)}

\section{a. Pengambilan darah sapi}

Darah sapi diambil dari rumah potong hewan Giwangan di Yogyakarta. Darah sapi ditampung setelah disembelih dengan menggunakan Falcon Tube. Kemudian ditambahkan ethylene deamine tetra acetic acis (EDTA) untuk mencegah penggumpalan darah. Perbandingan antara EDTA dan darah adalah 1:9.

\section{b. Pembuatan Platelet Rich Plasma}

Pembuatan Platelet Rich Plasma (PRP) dilakukan dengan sentrifugasi sebanyak dua kali untuk mendapatkan konsentrasi terapi. Darah yang sudah ditampung dalam Falcon Tube di sentrifus dengan kecepatan $2400 \mathrm{rpm}$ selama 10 menit. Bagian padat atau pellet dibuang, sehingga tertinggal bagian plasma saja. Plasma disentrifus dengan kecepatan 3600 rpm selama 15 menit. Bagian Platelet Rich Plasma dipisahkan dengan membuang bagian Platelet Poor Plasma memakai spet (Tozum, 2003).

\section{c. Pembuatan Krim PRP}

Platelet Rich Plasma (PRP) yang sudah didapat selanjutnya dapat dicampurkan dengan basis krim agar mudah untuk menggunakannya saat dioleskan ke kulit tikus. Krim PRP yang digunakan memiliki konsentrasi $20 \%$, dimana untuk mendapatkan konsentrasi 20\% yaitu dengan cara mencampur 10 gram basis krim dan $2 \mathrm{ml}$ PRP.

\section{Pengujian Pada Hewan Coba}

\section{a. Pengadaptasian hewan}

Selama satu minggu awal, tikus di adaptasikan pada kandang di laboratorium Hewan Coba FKH UGM. Hewan diberi makan dan minum. Jumlah tikus yang dipakai sebanyak 20 ekor.

\section{b. Induksi diabetes pada tikus}

Tikus yang telah dipuasakan 12 jam di induksi diabetes dengan Streptozotocin (STZ) dengan dosis 65 $\mathrm{mg} / \mathrm{kgBB}$ secara intraperitonial dan nicotinamide 235 $\mathrm{mg} / \mathrm{kgBB}$. STZ dencerkan dengan larutan penyangga sodium citrate, $\mathrm{pH} 4,5$. Tikus diperiksa kadar gula darahnya dengan alat Spectrofotometer pada hari ke 5. Tikus yang mempunyai kadar glukosa puasa diatas 200 $\mathrm{mg} /$ dl digunakan dalam penelitian ini.

\section{c. Pemberian perlakuan pada tikus}

Tikus dipuasakan dahulu selama 12 jam. Tikus kemudian ditimbang berat badannya untuk menentukan dosis yang paling tepat. Tikus dianestesi menggunakan ketamine dengan dosis $90 \mathrm{mg} / \mathrm{KgBB}$ Intramuskular diantara muskulus semitendineus dan semimembranosus. Setelah tikus teranestesi, tikus dilukai secara metode biopsy yaitu mengambil jaringan kulit membulat dengan diameter $1 \mathrm{~cm}$. Tikus dibagi dalam 4 kelompok tiap kelompok terdiri dari 5 ekor tikus. Ke empat kelompok tersebut adalah kelompok non diabetes diberi placebo (ND-), kelompok diabetes diberi placebo (DM), kelompok diabetes sebagai diberi obat komersil yang mengandung kloramfenikol basa $20 \mathrm{mg}+$ prednisolon 2,5 mg (DM+) dan kelompok diabetes diberi krim PRP dengan konsentrasi 20\% (DM PRP). Tikus diberi perlakuan selama 14 Hari. Jaringan kulit tikus diambil pada hari ke 3, 7, dan 14. Pada hari ke 3, 7, 11, dan 14 dilakukan pengukuran diameter luka menggunakan milimeter blok sehingga didapatkan besaran diameter luka yang tepat. 


\section{Analisis Hasil}

Parameter yang dipakai dalam evaluasi kesembuhan adalah diameter luka dan pemeriksaan histopatologi. Diketahui ada tidaknya perbedaaan kesembuhan luka dengan melihat diameter luka. Analisis data yang digunakan adalah Anova One Way dengan derajat signifikasi 95\%. Pemeriksaan histopatologi yang dapat dilihat adalah epitelialisasi, membrana basalis, fibroblast, jaringan kolagen, dan ada tidaknya sel radang dengan pembuatan preparat histopatologi. Uji histopatologi menggunakan pengecatan HE. Masing-masing pemeriksaan histopatologi dilakukan skoring.

Tabel 1. Skoring epitelisasi jaringan (Gal, 2008)

\begin{tabular}{cl}
\hline Skor & \multicolumn{1}{c}{ Keterangan } \\
\hline 1 & tidak/belum ada proses pembentukan epithel pada epidermis \\
2 & mulai pembentukan epithel pada epidermis, belum menutup $(<50 \%)$ \\
3 & pembentukan epithel tahap awal, ketebalan sedang, belum menutup $(\geq 50 \%)$ \\
4 & pembentukan epithel terstuktur, ketebalan tebal, sudah menutupi permukan epidermis \\
5 & tampak epithel sudah menutupi bagian epidermis \\
& \\
Tabel 2. Skoring membrana basalis $($ Gal, 2008) \\
\hline Skor & \\
\hline 1 & belum terbentuk lapisan membrana basalis \\
2 & tahap awal pembentukan membrana basalis ditandai dengan adanya lapisan tipis \\
3 & tahap ke 2 pembentukan membrana basalis ditandai dengan adanya lapisan sedang \\
4 & lapisan membrana basalis tebal tetapi masih belum tersusun secara rapi \\
5 & lapisan membrana basalis tebal tersusun rapi dan terlihat kembali normal
\end{tabular}

Tabel 3. Skoring jaringan kolagen (Gal, 2008)

\begin{tabular}{cl}
\hline Skoring & \multicolumn{1}{c}{ Keterangan } \\
\hline 1 & belum terdapat jaringan ikat kolagen \\
2 & serabut tipis berlubang besar mulai terbentuk \\
3 & lapisan tipis jaringan ikat kolagen belum menutupi seluruh dermis \\
4 & lapisan dermis banyak terisi jaringan ikat kolagen \\
5 & lapisan dermis terisi penuh jaringan ikat kolagen padat dan terlihat kembali normal \\
\hline
\end{tabular}

Tabel 4. Skoring fibroblast (Gal, 2008)

\begin{tabular}{cl}
\hline Skoring & \multicolumn{1}{c}{ Keterangan } \\
\hline 1 & tidak ada Fibroblast \\
2 & sedikit Fibroblast \\
3 & fibroblast dalam jumlah sedang \\
4 & banyak Fibroblast \\
5 & fibroblast dalam jumlah yang sangat banyak \\
\hline
\end{tabular}


Rahmad Dwi Ardiansyah, et. al.

Tabel 5. Skoring infiltrasi sel radang (Gal, 2008)

\begin{tabular}{cl}
\hline Skoring & \multicolumn{1}{c}{ Keterangan } \\
\hline 1 & tidak ada infiltrasi sel radang \\
2 & sedikit infiltasi sel radang \\
3 & infiltrasi sel radang dalam jumlah sedang \\
4 & banyak infiltrasi sel radang \\
5 & infiltrasi sel radang dalam jumlah yang sangat banyak \\
\hline
\end{tabular}

Hasil kesembuhan luka yang terbaik ditunjukkan bahwa epitelisasi sudah menutupi epidermis, membrana basalis tebal tersusun rapi, terdapat jaringan ikat kolagen padat memenuhi bagian dermis, fibroblast dalam jumlah yang sedang dan tidak terdapatnya infiltrasi sel radang.

\section{Hasil dan Pembahasan}

Data hasil pengukuran luka setiap 3 hari, dihitung dari diameter luka menggunakan milimeter blok dapat dilihat pada Tabel 6.

Tabel 6. Ukuran luka $(\mathrm{cm})$ tikus diabetes yang diberi perlakuan kontrol, obat komersil dan Prima Krim setiap 3 hari

\begin{tabular}{lccccc}
\hline \multirow{2}{*}{ Kelompok } & 0 & 3 & Hari ke- & 11 & 14 \\
\hline ND - & $1,50 \pm 0$ & $1,50 \pm 0,00$ & $1,05 \pm 0,06$ & $0,7 \pm 0,15$ & $0,30 \pm 0,06^{\mathrm{c}}$ \\
DM - & $1,50 \pm 0$ & $1,48 \pm 0,04$ & $1,05 \pm 0,06^{\mathrm{ac}}$ & $0,6 \pm 0,17^{\mathrm{ac}}$ & $0,40 \pm 0,17^{\mathrm{c}}$ \\
DM + & $1,50 \pm 0$ & $1,50 \pm 0,00$ & $1,35 \pm 0,06^{\mathrm{ab}}$ & $1,13 \pm 0,15^{\mathrm{ab}}$ & $1,07 \pm 0,06^{\mathrm{ab}}$ \\
DM PRP & $1,50 \pm 0$ & $1,48 \pm 0,04$ & $0,63 \pm 0,13^{\mathrm{abc}}$ & $0,23 \pm 0,25^{\mathrm{abc}}$ & $0,10 \pm 0,23^{\mathrm{ac}}$ \\
\hline
\end{tabular}

Keterangan:

ND - : Kelompok Nondiabetes kontrol negatif (diberi Placebo), DM - : Kelompok Diabetes Melitus kontrol negatif (diberi Placebo), DM+ : Kelompok Diabetes Melitus kontrol Positif (diberi kloramfenikol dan prednisolon), DM PRP : Kelompok Diabetes Melitus dengan pemberian Krim PRP konsentrasi 20\%.

${ }^{a, b, c}$ Superskrip yang berbeda menunjukkan perbedaan yang bermakna $(\mathrm{P}<0,05)$

Luka pada tikus diabetes yang diberikan obat dengan krim PRP 20\% (DM PRP) memiliki waktu kesembuhan luka lebih cepat daripada kelompok non diabetes diberi placebo (ND-), kelompok diabetes diberi placebo (DM-), kelompok diabetes sebagai diberi obat komersil yang mengandung kloramfenikol basa $20 \mathrm{mg}$ dan prednisolon 2,5 $\mathrm{mg}(\mathrm{DM}+)$. DM PRP memiliki waktu kesembuhan paling cepat dibandingkan kelompok yang lain, yaitu pada hari ke 11 sudah tidak ada luka. Gambar makroskopik luka setelah 14 hari dapat dilihat pada Gambar 2 . 


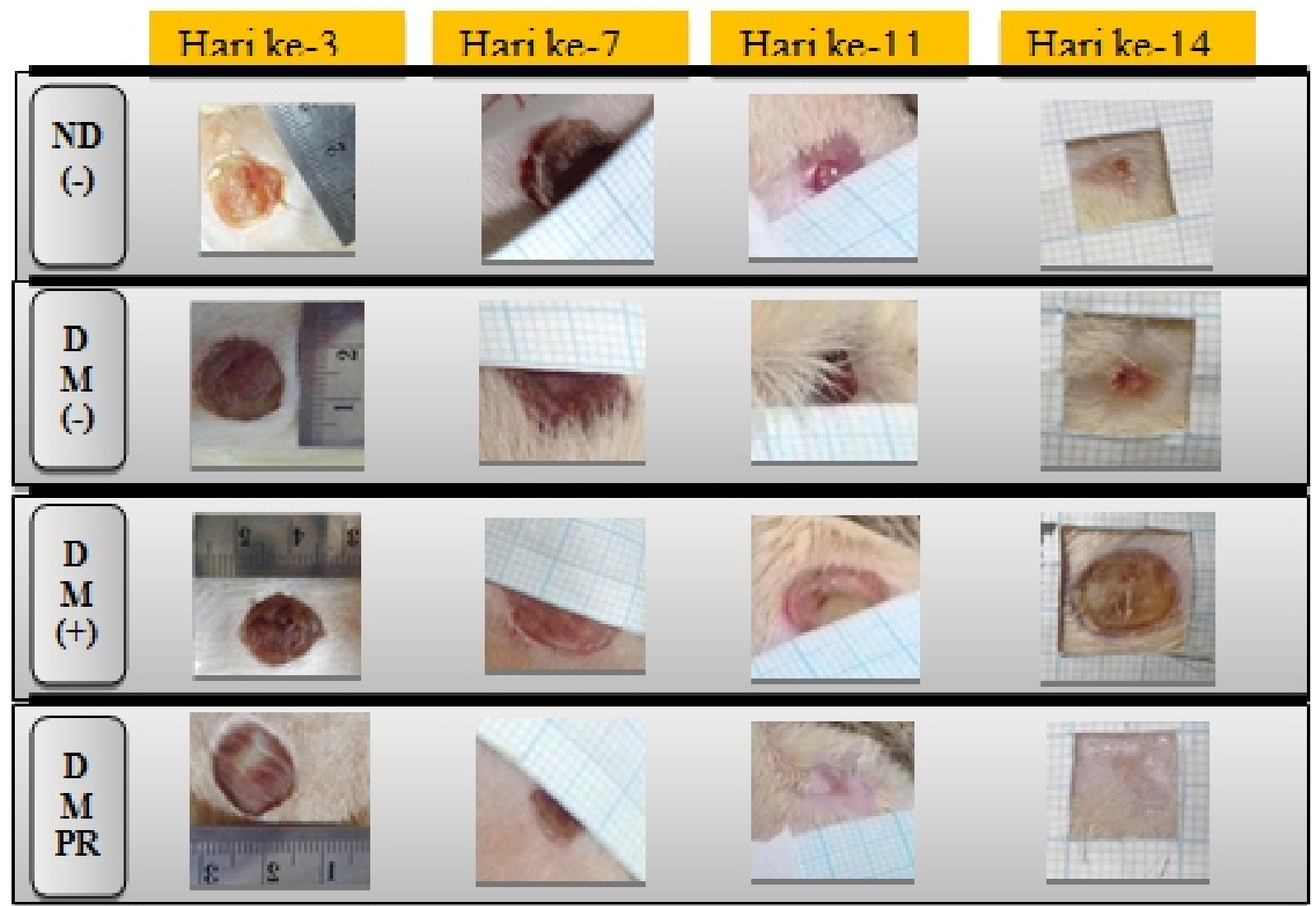

Gambar 1. Perkembangan kesembuhan luka pada hari ke 3, 7, 11 dan 14.
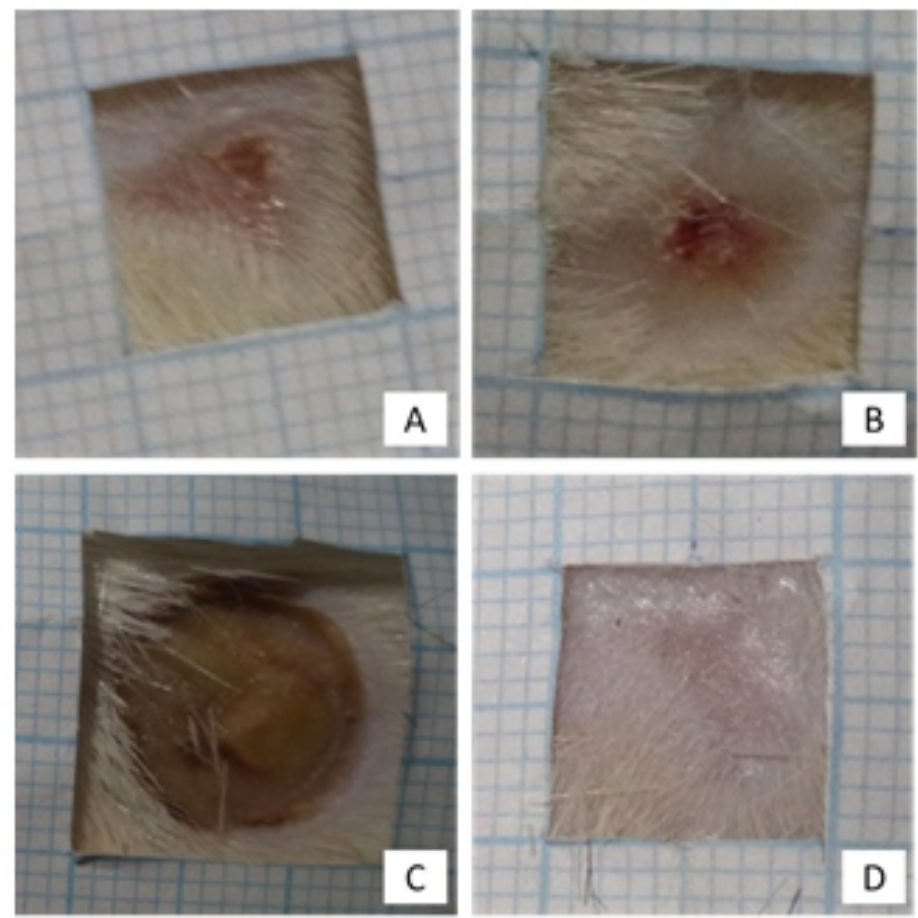

Gambar 2. Gambaran makroskopik luka setelah 14 hari. A) Kelompok non diabetes diberi placebo (ND-); B) Kelompok diabetes diberi placebo (DM); C) kelompok diabetes diberi obat komersil yang mengandung kloramfenikol basa $20 \mathrm{mg}+$ prednisolon 2,5 mg (DM+); D) Kelompok diabetes diberi krim PRP dengan konsentrasi 20\%(DM PRP). 
Rahmad Dwi Ardiansyah, et. al.

Gambar 1 menunjukkan pada hari ke-14 luka pada kelompok DM PRP telah sembuh. Hasil analisis dengan metode One-way Analsisis of variance (Anova) menunjukkan bahwa pada hari ke3 tidak ada perbedaan signifikan pada seluruh kelompok. Hari ke-7 seluruh kelompok terdapat perbedaan signifikan dengan DM PRP, antara kelompok ND (-) dan DM (-) tidak ada perbedaan signifikan. Hari ke-11 Seluruh kelompok terdapat perbedaan signifikan dengan DM PRP, antara ND (-) dan DM (-) tidak ada perbedaan signifikan. Hari ke14 DM PRP dengan ND- dan DM+ ada perbedaan signifikan. Hal ini menunjukkan bahwa DM PRP memiliki tingkat kesembuhan lebih cepat dibandingkan kelompok lain.

Hasil pembacaan preparat histopatologi menunjukkan bahwa tipe kesembuhan luka bervariasi pada masing-masing perlakuan. Gambaran histopatologi kulit pada hari ke-14 dapat dilihat pada Gambar 3 di bawah ini.
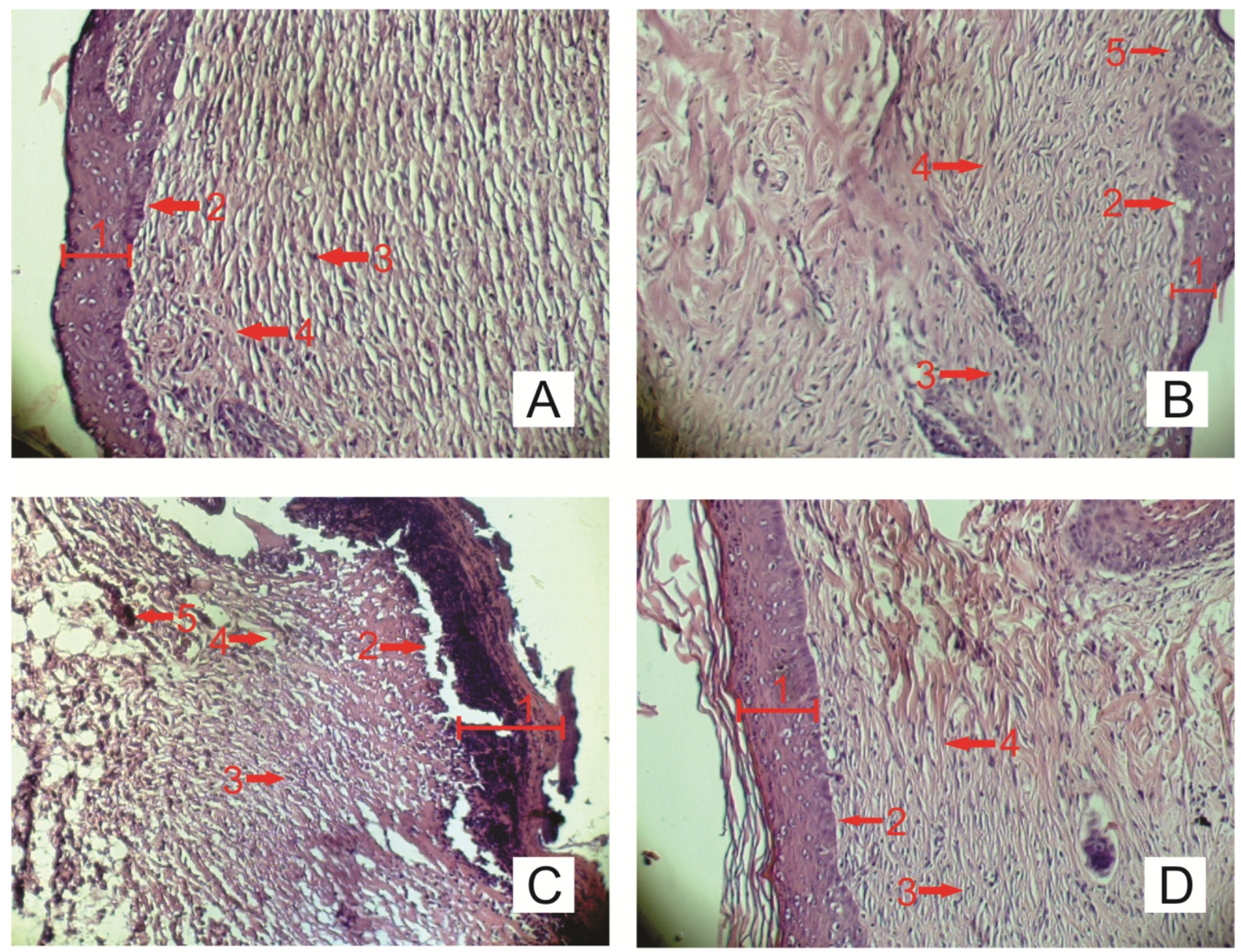

Gambar 3. Gambaran histopatologi kulit luka setelah 14 hari perlakuan dengan A) Kelompok non diabetes diberi placebo (ND-); B) Kelompok diabetes diberi placebo (DM-); C) kelompok diabetes sebagai diberi obat komersil yang mengandung kloramfenikol basa $20 \mathrm{mg}+$ prednisolon 2,5 mg (DM+); D) Kelompok diabetes diberi krim PRP dengan konsentrasi 20\% (DM PRP) dengan Epitelialisasi (1); Membrana basalis (2); Fibroblast (3); Jaringan kolagen (4); Sel radang (5) (HE, 10 x 10) 
Berdasarkan pembacaan preparat histopatologi, didapatkan hasil bahwa epitelisasi kelompok DM PRP terdapat perbedaan bermakna dengan kelompok ND-, DM-, dan DM+ dengan skor $4,67 \pm 0,58$. Epitelisasi kelompok ND-, DM- dan DM+ memiliki skor berturut-turut $3,67 \pm 0,58 ; 3,00 \pm 0,00$; $1,00 \pm 0,00$. Membrana basalis kelompok ND-, DM-, DM+ dan DM PRP memiliki skor berturut-turut $3,67 \pm 0,58 ; 3,00 \pm 0,00 ; 1,67 \pm 0,58 ;$ dan $3,33 \pm 0,58$. Membrana basalis kelompok DM PRP terdapat perbedaan bermakna dengan kelompok DM+. Fibroblast kelompok ND-, DM-, DM+ dan DM PRP memiliki skor berturut-turut $4,33 \pm 0,58 ; 4,00 \pm 0,00$;

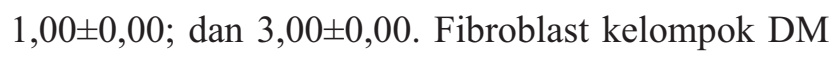
PRP terdapat perbedaan bermakna dengan kelompok $\mathrm{DM}+$. Jaringan ikat kolagen kelompok ND-, DM-, $\mathrm{DM}+$ dan DM PRP memiliki skor berturut-turut $3,00 \pm 0,00 ; 4,00 \pm 0,00 ; 2,33 \pm 0,58 ;$ dan $4,00 \pm 0,00$. Jaringan ikat kolagen kelompok DM PRP terdapat perbedaan bermakna dengan kelompok DM+. Berdasarkan ada tidaknya infiltrasi sel radang didapatkan hasil skor pada kelompok ND-, DM-, DM+ dan DM PRP berturut-turut 3,67 $\pm 0,58 ; 4,00 \pm 0,00$; $5,00 \pm 0,00$ dan $1,00 \pm 1,00$. Infiltrasi sel radang kelompok DM PRP $20 \%$ terdapat perbedaan bermakna dengan kelompok ND-, DM-, dan DM+.

Hasil kesembuhan luka yang terbaik ditunjukkan bahwa epitelisasi sudah menutupi epidermis, membrana basalis tebal tersusun rapi, terdapat jaringan ikat kolagen padat memenuhi bagian dermis, fibroblast dalam jumlah yang sedang dan tidak terdapatnya infiltrasi sel radang. Berdasarkan hasil pemeriksaan histologi diatas, kelompok DM PRP menunjukkan bahwa tingkat kesembuhan luka secara histologi lebih baik daripada kelompok ND-, DM-, dan $\mathrm{DM}+$.

Luka diabetik dikarakteristikkan sebagai luka kronis yang memiliki waktu penyembuhan yang lama.
Menurut Brem dan Marjana (2007) terdapat faktor fisiologi yang berkontribusi terhadap defisiensi penyembuhan luka pada individu dengan diabetes. Meliputi penurunan atau gangguan produksi growth factor, respon angiogenesis, fungsi makrofag, akumulasi kolagen, fungsi batas epidermis, jumlah jaringan granulasi, keratinosit, migrasi dan proliferasi fibroblas, jumlah saraf epidermal, penyembuhan tulang, serta keseimbangan antara akumulasi komponen matriks ekstraseluler (ECM) dan remodelling oleh matriks metalloproteinase (MMPs).

PRP mengandung growth factor yang dapat mempercepat penyembuhan tulang dan jaringan lunak. Menurut Eppley dkk (2006) protein yang terkandung dalam $\alpha$-granule dari platelet yang sangat berpengaruh pada kesembuhan luka, termasuk didalamnya adalah Platelet-Derived Growth Factor (PDGF) dengan isomer $\alpha \alpha, \beta \beta$, dan $\alpha \beta$, Transformer Growth Factor (TGF)- $\beta$ dengan isomer $\beta 1$ dan $\beta 2$, Platelet Factor 4 (PF4), Interleukin (IL), Platelet-Derived Angiogenesis Factor (PDAF), Vascular Endothelial Growth Factor (VEGF), Epidermal Growth Factor (EGF), PlateletDerived Endothelial Growth Factor (PDEGF), Epithelial Cell Growth Factor (ECGF), Insulin-like Growth Factor (IGF), osteocalcin, osteonectin, fibrinogen, vitronectin, fibronectin, dan thrombospondin (TSP). Protein ini secara kolektif adalah anggota dari kelompok growth factor, cytokines, dan chemokines yang termasuk dalam protein sekretori. Ditambahkan Everts (2006) platelet juga mengandung Basic Fibroblast Growth Factor (bFGF), dan Connective Tissue Growth Factor (CTGF).

Berdasarkan parameter kesembuhan luka yaitu pengukuran diameter luka dan pemeriksaan histopatologi, dapat dinyatakan bahwa DM PRP memiliki tingkat kesembuhan lebih baik dibandingkan kelompok ND-, DM-, dan DM+. Hal ini membuktikan 
Rahmad Dwi Ardiansyah, et. al.

bahwa Krim PRP yang berasal dari limbah darah sapi mampu menyembuhkan luka pada penderita Diabetes Melitus secara optimal.

Berikut ini merupakan peran platelet pada tahap kesembuhan luka: 1) Degranulasi Platelet: Setelah kerusakan jaringan, PDGF dan FGF mulai diproduksi oleh sel yang terluka. Platelet membentuk sumbat pada tempat itu, dan akan memulai degranulasi dengan merilis growth factor, PDGF dan TGF- $\beta$ adalah growth factor yang sangat penting pada tempat luka dan mulai melakukan proses penyembuhan luka. Karakteristik dari molekul PGF adalah kemotaktik dan mitogenik yang berhubungan dengan sel radang seperti neutrofil, monosit, dan makrofag. 2) Aksi Inflamasi: dosis tunggal PDGF yang diberikan pada lika incisi menunjukkan bahwa terjadi respon radang dengan peningkatan pemasukan netrofil dan makrofag. 3) Deposisi Matrik: fase sintesis matrik dan deposisi matrik, PGF kembali melakukan peran predominan. Dosis tunggal dari PDGF dalam penelitian meningkatkan volume granulasi jaringan sebesar $200 \%$ setelah 7 hari. Pemberian TGF- $\beta$ secara tunggal pada luka, itu menyatakan bahwa matrik sebagian besar membentuk kolagen baru. 4) Produksi Kolagen: Produksi koagen kolagen sangat penting dalam penyembuhan luka, yang diinisiasi aksi kemotaktik dan mitogenik dari fibroblast oleh FGF. 5) Epitelialisasi: Pemberian secara topikal Epidermal Growth Factor (EGF) memulai untuk mempercepat epitelialisasi. PDGF sangat penting dalam epitelialisasi, bersama dengan FGF meningkatkan kontraksi dan waktu remodeling (Everts dkk, 2006). Platelet juga mempunyai aktifitas antimikroba yang dapat mencegah terjadinya infeksi pada luka, platelet mengandung dan melepaskan protein yang bersifat mikrobisidal yaitu termed platelet microbicidal proteins (PMPs) atau thrombin-induced PMPs (tPMPs) jika dirangsang dengan mikroorganisme atau agonis trombosit berhubungan dengan infeksi pada vitro (Yeaman dan Arnold, 1999).

Berdasarkan bukti-bukti penelitian diatas, maka dimasa mendatang Prima Krim ini dapat dimanfaatkan untuk mengatasi luka pada penderita diabetes melitus tanpa menimbulkan bekas luka dan menghindari terjadinya tindakan amputasi yang sering terjadi pada penderita diabetes melitus

\section{Kesimpulan}

Prima krim yang mengandung PRP dari limbah darah sapi terbukti mampu menyembuhkan luka pada penderita diabetes melitus dengan parameter diameter luka menggunakan pengukuran milimeter blok dan hasil pemeriksaan histologi. Pada pengukuran diameter luka, PRP mampu menyembuhkan luka pada hari ke-11 dibuktikan dengan tidak terdapatnya bekas luka. Pada pemeriksaan histologi, PRP memiliki kesembuhan yang optimal ditandai dengan epitelisasi sudah menutupi epidermis, membrana basalis tebal tersusun rapi, terdapat jaringan ikat kolagen padat memenuhi bagian dermis, fibroblast dalam jumlah yang sedang dan tidak terdapatnya infiltrasi sel radang. Prima Krim merupakan solusi penyembuh luka pada penderita diabetes melitus yang efisien tanpa meninggalkan bekas luka.

\section{Ucapan Terima kasih}

Terima kasih kami sampaikan kepada Kementerian Riset, Teknologi dan Pendidikan Tinggi yang telah mendanai penelitian ini melalui Program Kreatifitas Mahasiswa (PKM), sehingga penelitian ini dapat dilaksanakan.

\section{Daftar Pustaka}

Anonim. (2010). Peraturan Menteri Pertanian Nomor 13/Permentan/Ot.140/1/2010 Tentang Persyaratan Rumah Potong Hewan Ruminansia Dan Unit Penanganan Daging (Meat Cutting 
Plant). Kementrian Pertanian Republik Indonesia

Anonim. (2013). IDF Diabetes Atlas 6rd Edition. International Diabetes Federation (IDF). http://www.idf.org/sites/default/files/EN_6E Atlas_Full_0.pdf.Diakses 17 Oktober 2014

Ardhiansyah, R.D., Baihaqie, R.P., Naufal, M.N.N., Nanda, M.A.F., Maharani, A., dan Fibrianto, Y.H. (2014). Laporan Penelitian PKM: Platelet Rich Plasma (PRP) dari Limbah Darah Sapi sebagai Obat Luka Bakar. Yogyakarta: Universitas Gadjah Mada

Brem, H dan Marjana, T.C. (2007). Cellular and molecular basis of wound healing in diabetes. $J$. Clin. Invest. 117:1219-1222

Eppley, B.L., Pietrzak, W.S., dan Blanton M. 2006. Platelet-Rich Plasma: A Review of Biology and Applications in Plastic Surgery. Plastic Reconstructive Surgery Volume 118 (6)

Everts, P.A.M., Johannes, T.A.K., Gernot, W., Jacques P.A.M.S., Johannes H., Eddy, P.O., Hemk A.M.B., dan Andre, V.Z. (2006). Platelet-Rich Plasma and Platelet Gel: A Review. JECT, 2006:38:174-187

Gal, P., Kilik, R., Mokry, M., Vidinsky, B., Vasilenko, T., Vasilenko, T., Mozes, R., Bobrov, N., Tomori, Z., Bober, J. \& Lenhardt. (2008). Simple Method of Open Skin Wound Healing Model in Corticosteroid-treated and Diabetic Rats: Standardization of Semi-quantitative and Quantitative Histological assessments. Veterinarni Medicina, 53, 2008 (12): 652-659

Margolis, D.J., Kantor, J., dan Berlin, J.A. (1999). Healing of Diabetic Neuropathic Foot Ulcers Receiving Standard Treatment, A meta-analysis. Diabetes Care vol. 22 no. 5 692-695

Marx, Robert E. (2001). Platelet-Rich Plasma (PRP): What Is PRP and What Is Not PRP?. Implant Dentistry Vol. 10 No. 4. USA: Lippincott Williams \& Wilkins

Sanjaya A.W., Sudarwanto M., dan Pribadi E.S. (1996). Pengelolaan Limbah Cair Rumah Potong Hewan di Kabupaten Dati II Bogor. Bogor: Media Veteriner Vol III (2)

Yeaman, M.R. dan Arnold, S.B. (1999). Antimicrobial peptides from platelets. Drug Resist Updat Volume 2, Issue 2, Pages 116-126

Tozum T.F., dan Demiralp B. (2003). Platelet-Rich Plasma: A Promising Innovation in Dentistry. di dalam Clinical Practice Canada: Journal of the Canadian Dental Association. Vol 69 No 10 